\title{
THE EFFECT OF SALINITY, TEMPERATURE AND GAMETE DENSITY ON THE EMBRYONIC DEVELOPMENT OF THE SLIPPER OYSTER, CRASSOSTREA IREDALEI FAUSTINO
}

\author{
Achmad Sudradjat*
}

\begin{abstract}
The study was designed to investigate effects of temperature, salinity and gamete density in the percentage of embryos that develop into normal D-larvae of Crassostrea iredalei $30 \mathrm{~h}$ after fertilization. Gametes were obtained by stripping mature oysters. It was found that the optimum salinity for embryonic development was relatively wide being between 25-35 ppt. Satisfactory development of embryos into normal D-larvae was possible at salinities from 15-35 ppt. Normal development of embryos into the D-larval stage occured over a wide range of temperature $\left(14^{\circ}-34^{\circ} \mathrm{C}\right)$. The optimum temperature range for embryonic development was $19^{\circ}-29^{\circ} \mathrm{C}$. Six levels of gamete density were tested to define the variation of embryonic development. The highest percentage of normal D-larvae was at density levels of $1 \times 10^{4}, 2.5 \times 10^{4}$ and $5 \times 10$ per litre; producing $81.7,79.6$ and $71.4 \%$ respectively
\end{abstract}

KEYWORDS: Salinity, temperature, gamete, embryo, slipper oyster.

\section{INTRODUCTION}

The studies on culture methods for bivalves are extensive, not least because of commercial interests in certain species. The basic methods of rearing bivalve embryos and larvae are described in papers by Loosanoff and Davis (1963) and Walne $(1974,1981)$. Early embryonic stages of bivalves are more sensitive to environmental changes than adults (Calabrese \& Davis, 1970). Effects of different temperatures and salinities on embryonic and larval development of several bivalve species including Crassostrea virginica, Mulinia lateralis, Mytilus edulis, Pecten maximus and Argopecten irradians irradians have been reported (Davis and Calabrese, 1964; Calabrese, 1969; Hrs-Brenko and Calabrese, 1969; Gruffydd \& Beaumont, 1970; and Tettelbach and Rhodes, 1981).

Data on the influence of gamete density, salinity and temperature of C. rhizophorae for hatchery purposes has been reported by Dos Santos \& Nascimento (1985). Kalyanasundaram \& Ramam-oorthi (1986) observed the effect of temperature and salinity differences on embry. onic development of S. cucullata. Early development studies in $C$. iredalei from the Philippines at ambient temperature and salinity have been described by Ver (1986).

The present study was designed to investigate effects of temperature, salinity and gamete density in the percentage of embryos that develop into normal D-larvae of C. iredalei, as well as the effects of temperature and salinity on the size of normal D-larvae, 30 hours after fertilization.

\section{MATERIALS AND METHODS}

\section{Water Treatment}

Fine filtration of water was carried out using Sartorius capsule filter cartridge $(1.2 \mu \mathrm{m}$ and 0.20 $\mu \mathrm{m})$ and sterilization was achieved by passing the water through an ultraviolet light unit. Low. salinity water was prepared by diluting filtered seawater with distilled water. High-salinity water was made by adding synthetic sea salts. All

\footnotetext{
Researcher of Central Research Institute for Fisheries, Jakarta
} 
cultures were kept in constant temperature baths. The $\mathrm{pH}$ level of seawater was $7.2-8.1$, i.e. within the range regarded as optimal for oyster embryo's development (Calabrese \& Davis, 1966).

\section{Sources of Specimens}

Adult oysters to be used for these experiment were collected from Lada Bay (West Java). These oysters were air-freighted to the U.K. and placed in a special quarantine room with a closed circuit seawater system. Space heaters were used to maintain a room ambient temperature of $24-27^{\circ} \mathrm{C}$. A mixture of cultured microalgae of two species Isochrysis galbana (Clone T-ISO) and Pavlova lutheri used as oyster diet.

Gametes were obtained by stripping mature oysters. Male and female gametes were placed separately in glass beakers. Seawater salinity was $25 \mathrm{ppt}$, at $24^{\circ} \pm 1^{\circ} \mathrm{C}$. To eliminate excess pieces of gonadal tissue, eggs were sieved through $80 \mu \mathrm{m}$ nylon mesh screens and collected on $35 \mu \mathrm{m}$ mesh screens; sperm were sieved through $25 \mu \mathrm{m}$ mesh screens. Egg densities were determined by counting three samples taken under agitation with a perfo-rated perspex disk on a rod.

\section{Artificial Fertilization Experiments}

The methods of fertilization were partly based on Walne (1974) and Dos Santos and Nascimento (1985). The eggs were kept in test containers (250 $\mathrm{ml}$ glass beakers) under each experimental condition for $24 \mathrm{~h}(30 \mathrm{~h}$ for measuring size of normal D-larvae). All the experiments were made in duplicate and repeated 3 times. No specific set of conditions can be considered as "control" conditions in this study. Fertilization took place in a $250 \mathrm{ml}$ glass beaker after the appropriate volume of eggs and sperm suspension had been added. The suspension was gently stirred for a few minutes and then left without further stirring. Most gametes sank. After about $3 \mathrm{~h}$ two thirds of the seawater was decanted away and the volume made up with fresh seawater. Standard monitoring procedure was as follows.

After vigorous mixing a $10 \mathrm{ml}$ sample was taken from each beaker and preserved with $5 \%$ formalin. Embryos are defined here as the stage between the fertilized egg and the ciliated trocho pore. The normal larvae are defined as being perfectly D-shaped whilst abnormal larvae had irregular shaped shells (Dos Santos \& Nascimento, 1985). The numbers of embryos that developed normally and abnormally were counted. The eggs or larvae were counted and measured under a binocular microscope using a "Sedgewich Rafter" counting cell. About 50 eggs or larvae were measured for each treatment.

For the data analysis, the angular transformation $(\arcsin \sqrt{ } \%$ ) was used for the percentage of normal D-larvae before analysis of variance. For comparison between means the StudentNewman-Keuls test (Sokal \& Rohlf, 1981) was used.

Three kinds of experiments were conducted:

(1) Determination of the appropriate salinity range for the maximum production of normal D-larvae and effects of salinity differences on size of normal D-larvae. Eight different salinities between 5 and 40 ppt at 5 ppt interval were tested. Egg density and temperature were $10^{4}$ per litre and $24 \mathrm{C}$ respectively. Numbers of sperm were adjusted 100 per egg.

(2) Determination of the appropriate temperature range for the maximum production of normal D-larvae and effects of temperature on size of normal D-larvae. Five different temperature, $14^{\circ}, 19,24,29$ and $34 \mathrm{C}$ were tested. Salinity and egg density were 30 ppt and $10^{4}$ per litre; and sperm were 100 per egg.

(3) Determination of the optimum density of eggs for the maximum production of normal $D$-larvae. Six different egg densities per litre $\left(1 \times 10^{4}, 2.5 \times 10^{4}, 1 \times 10^{5}, 5 \times 10^{5}\right.$ and $1 \times 10^{6}$ ) were tested with 100 sperm per egg. Salinity and temperature were $30 \mathrm{ppt}$ and $24^{\circ} \mathrm{C}$.

\section{RESULTS}

\section{Effect of Salinity on the Embryonic Develop- ment}

Table 1 shows that at salinity 5 ppt no embryos developed to normal D-larvae. ANOVA results indicated significant differences in the 
percentage of normal D-larvae between treatments $(\mathrm{P}<0.05)$. The optimum salinity for embryonic development was relatively wide betwen 25-35 ppt (Figure 1). Although the data indicate that 30 ppt may be near the optimum, differences from neighbouring salinities were not significant.
The percentages of normal D-larvae produced at salinities of 25 and $35 \mathrm{ppt}$ were not significantly different $(\mathrm{P}>0.05)$. Satisfactory development of embryos into normal D-larvae was possible at salinities from $15-35 \mathrm{ppt}$ (59.2 to $81.7 \%$ normal D. larvae).

Table 1. Artificial fertilization of C. iredalei. Percentages of embryos developing to normal D-larvae at different salinities, 24 hours after fertilization. In all treatments, egg density and temperature were $1 \times 10^{4}$ per litre and $24^{\circ} \mathrm{C}$ respectively.

\begin{tabular}{|c|c|c|c|c|c|c|c|c|c|}
\hline \multirow{2}{*}{ Experiments } & & \multicolumn{8}{|c|}{ Salinity (ppt) } \\
\hline & & 5 & 10 & 15 & 20 & 25 & 30 & 35 & 40 \\
\hline \multirow[t]{2}{*}{1} & A & 0.0 & 11.8 & 49.5 & 62.5 & 69.0 & 70.0 & 65.5 & 7.1 \\
\hline & B & 0.0 & 14.4 & 65.7 & 66.7 & 75.4 & 74.4 & 76.4 & 0.0 \\
\hline \multirow[t]{2}{*}{2} & A & 0.0 & 9.5 & 71.4 & 74.2 & 76.7 & 80.0 & 73.3 & 12.8 \\
\hline & B & 0.0 & 7.1 & 66.0 & 71.9 & 83.1 & 83.7 & 78.6 & 7.0 \\
\hline \multirow[t]{2}{*}{3} & A & 0.0 & 10.2 & 55.5 & 55.1 & 88.7 & 91.6 & 86.1 & 6.3 \\
\hline & B & 0.0 & 7.0 & 46.8 & 73.6 & 79.3 & 90.3 & 88.8 & 8.2 \\
\hline $\bar{x}$ & & 0.0 & 10.0 & 59.2 & 67.3 & 78.7 & 81.7 & 78.1 & 6.9 \\
\hline S.D. & & 0.0 & 2.84 & 9.99 & 7.49 & 6.76 & 8.59 & 8.53 & 4.11 \\
\hline
\end{tabular}

The highest mean length was recorded at salinity of $25 \mathrm{ppt}$ (Figure 2). There was a significant difference between mean length of normal D-larvae at salinity of 25 and those at salinities of 20,30 and 35 ppt $(\mathrm{P}<0.05)$.

\section{Effect of Temperature on Embryonic Develop- ment}

Normal development of embryos into the D-larvae stage occurred over a wide range of temperature $\left(14^{\circ}-34^{\circ} \mathrm{C}\right)$. ANOVA results indicated significant differences in the percentage of normal D-larvae between treatments (Table 2). The optimum temperatures for embryonic development to normal D-larvae were $19^{\circ}$ to $29^{\circ} \mathrm{C}$, and resulted in high percentages of normal D-larvae (74.0 to $81.0 \%$ ) (Figure 3 ). The percentages of normal D-larvae at temperatures of $14^{\circ} \mathrm{C}$ and $34^{\circ} \mathrm{C}$ were low (5.6 and $41.8 \%$ ).

The mean length of normal D-larvae at differ- ent temperature ( $30 \mathrm{~h}$ after fertilization) are shown in Figure 4. There was a significant difference $(\mathrm{P}<0.05)$ in size of normal $\mathrm{D}$-larvae between temperature $19^{\circ}, 24^{\circ}$ and $29^{\circ} \mathrm{C}$. The highest mean length recorded was at temperature of $29^{\circ} \mathrm{C}$ mean length $=70.3 \mu \mathrm{m}$ ).

\section{Effect of Gamete Density on the Embryonic Development}

There were 6 levels of gamete density in this experiment to test variations of embryonic development into normal D-larvae. The highest percentages of normal D-larvae of $C$. iredalei were at egg densities of $1 \times 10^{4}, 2.5 \times 10^{4}$ and $5 \times 10^{4}$ per litre (Table 3 and Figure 5); it recorded 81.7, 79.6 and $71.4 \%$ respectively. These values were not significantly different $(\mathrm{P}>0.05)$. The percentage of normal D-larvae decreased to $60.9,10.5$ and $6.5 \%$ when the egg densities were increased to $1 \times 10^{5}$, $5 \times 10^{5}$ and $1 \times 10^{6}$ per litre. 


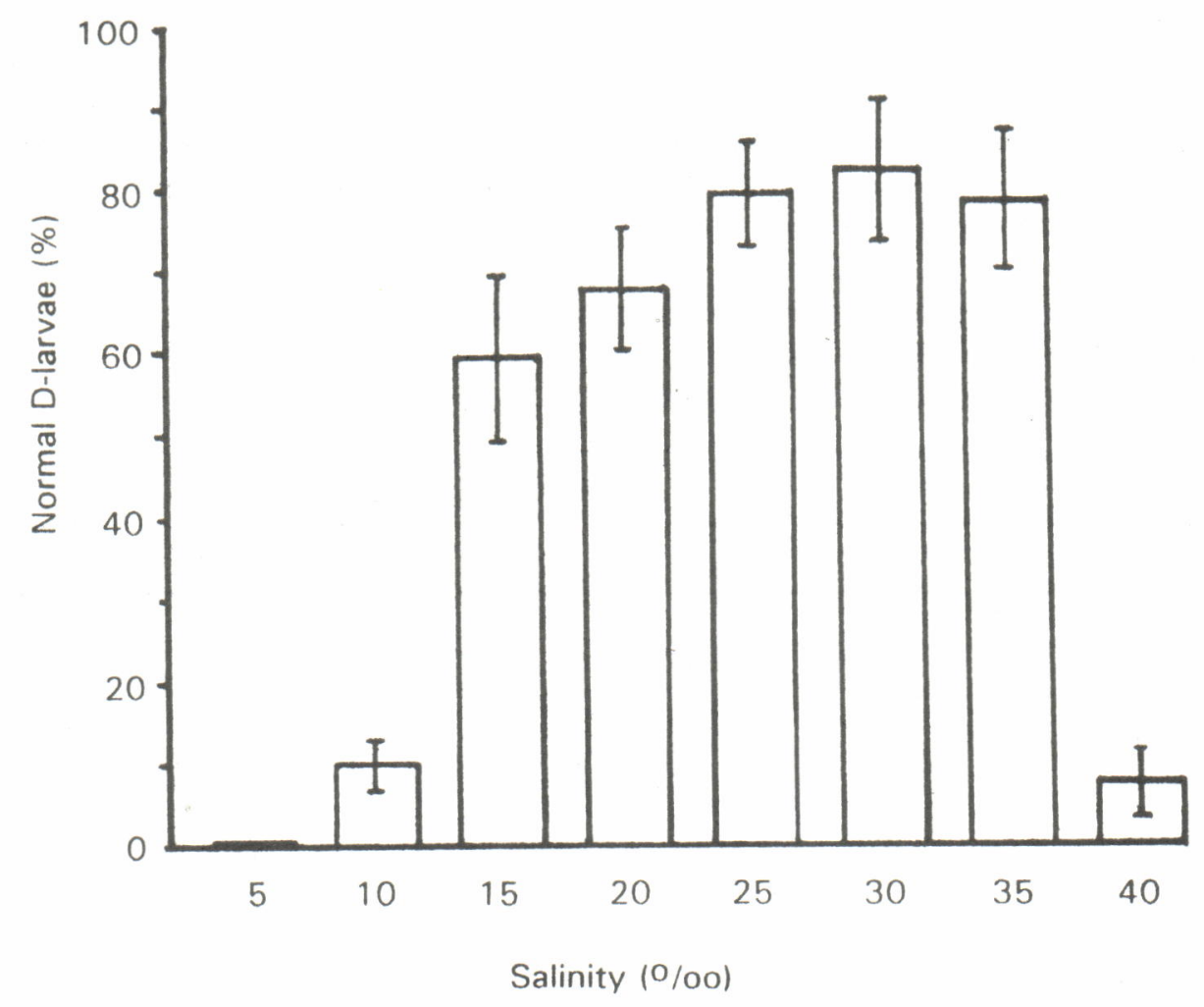

Figure 1. C. iredalei. Percentage of eggs that developed into normal D-larvae at different salinities. Temperature and egg density were $24^{\circ} \mathrm{C}$ and $10^{4}$ per litre. Standard deviations are also shown.

Table 2. Artificial fertilization of C. iredalei. Percentages of embryos developing to normal D-larvae at different temperatures, $24 \mathrm{~h}$ after fertilization. In all treatments, egg density and salinity were $1 \times 10^{4}$ per litre and $30 \mathrm{ppt}$ respectively.

\begin{tabular}{ccccccc}
\hline \multirow{2}{*}{ Experiments } & \multicolumn{5}{c}{ Temperature $\left({ }^{\circ} \mathbf{C}\right)$} \\
\cline { 3 - 7 } & & $\mathbf{1 4}$ & $\mathbf{1 9}$ & $\mathbf{2 4}$ & $\mathbf{2 9}$ & $\mathbf{3 4}$ \\
\hline \multirow{2}{*}{1} & $\mathrm{~A}$ & 7.5 & 66.4 & 70.0 & 67.3 & 39.8 \\
& $\mathrm{~B}$ & 3.6 & 65.3 & 69.8 & 67.3 & 41.2 \\
2 & $\mathrm{~A}$ & 0.0 & 74.4 & 80.3 & 72.1 & 63.2 \\
& $\mathrm{~B}$ & 5.1 & 75.0 & 83.7 & 88.9 & 43.9 \\
& $\mathrm{~A}$ & 8.2 & 77.1 & 91.6 & 88.3 & 29.8 \\
& $\mathrm{~B}$ & 9.4 & 85.7 & 90.3 & 91.2 & 32.8 \\
& $\mathrm{~B}$ & 5.6 & 74.0 & 81.0 & 79.2 & 41.8 \\
\hline & & 3.48 & 7.50 & 9.52 & 11.44 & 11.76 \\
\hline
\end{tabular}




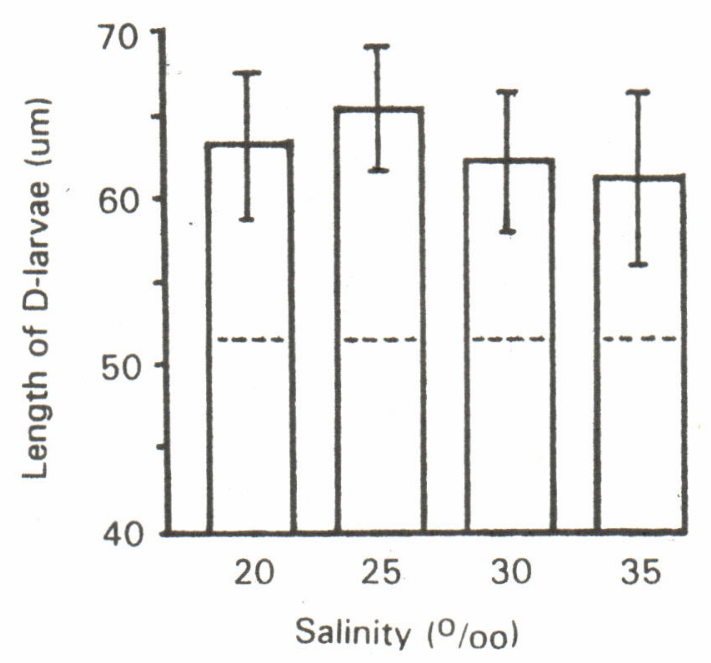

Figure 2. C. iredalei. The mean length of normal D-larvae at different salinities, $30 \mathrm{~h}$ after fertilization. Standard deviations are shown.

..... mean egg diameter.

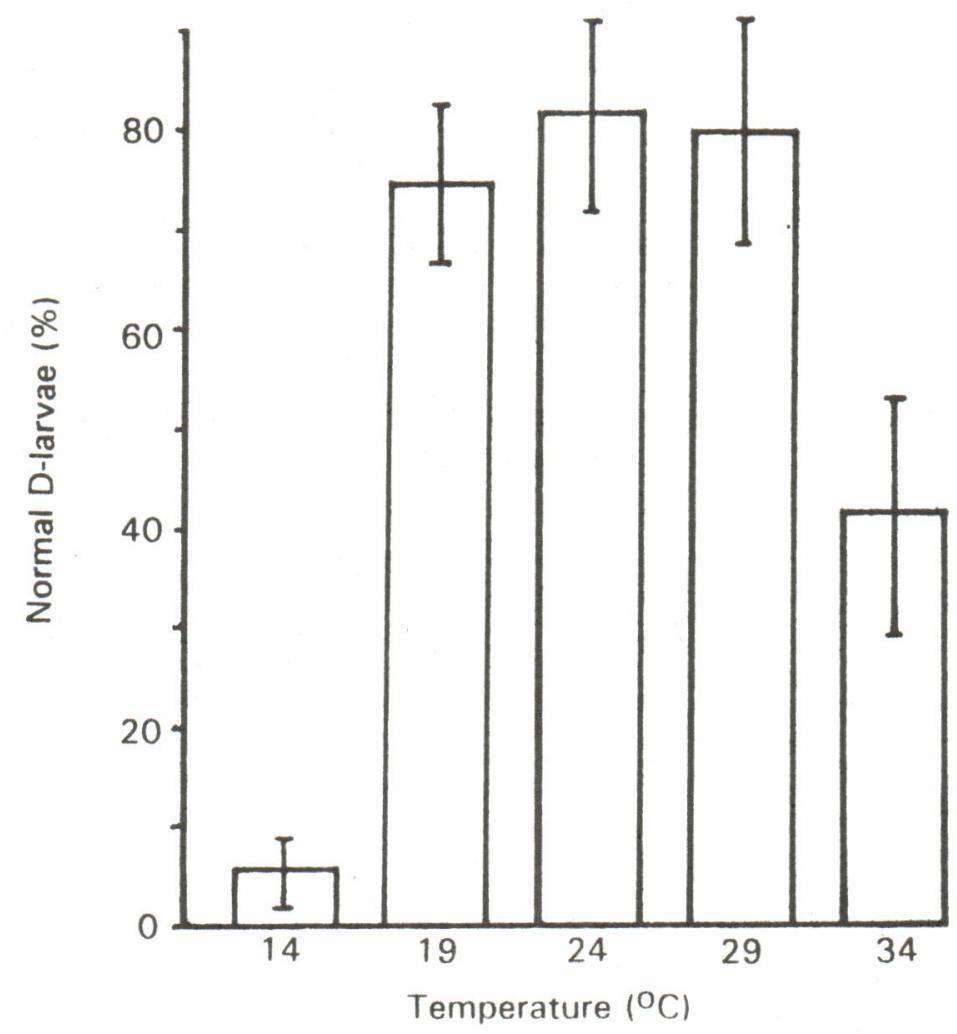

Figure 3. C. iredalei. Percentage of eggs that developed into normal D-larvae at different temperature. Salinity and egg density were $30 \mathrm{o} / \mathrm{oo}$ and $10^{4}$ per litre. Standard deviations are also shown. 
Sudradjat, $A$.

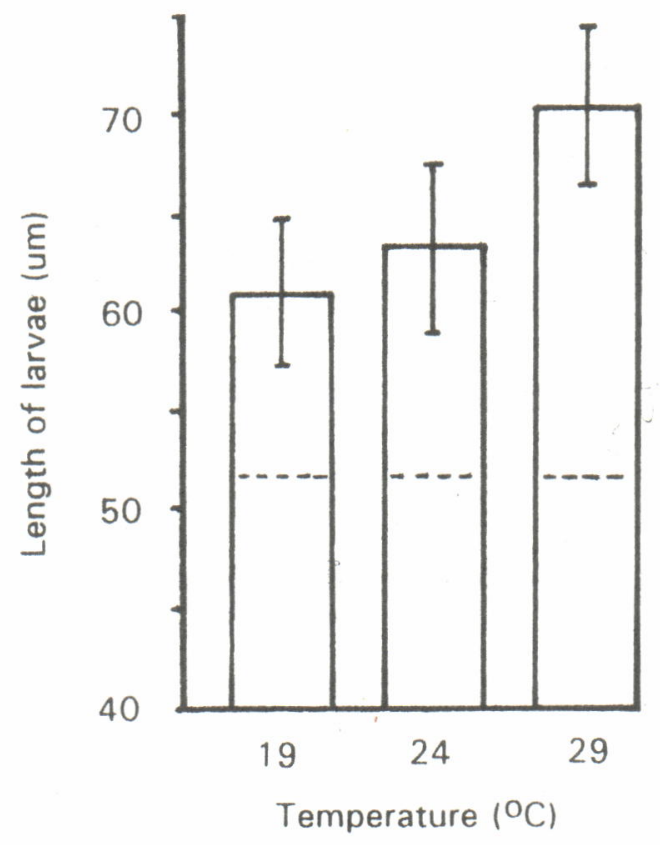

Figure 4. C. iredalei. The mean length of normal D-larvae at different temperatures, $30 \mathrm{~h}$ after fertilization. Standard deviations are shown.

....--mean egg diameter

\section{DISCUSSION}

\section{Effects of Salinity and Temperature}

The early embryonic stages are easily influenced by the environment. Salinity and temperature are two environmental factors of primary importance for successful development of oyster larvae (Galtsoff, 1964). Studies on the effects of salinity and temperature on embryonic development on temperate oysters have been reported by Amemiya (1928), Davis and Calabrese (1964), Helm \& Millican (1977). For tropical oysters, Dos Santos and Nascimento (1985) reported that optimal temperature and salinity for embryonic development of C. rhizophorae were between $20^{\circ}$

Table 3. Artificial fertilization of C. iredalei. Percentages of embryos developing to normal D-larvae at different egg densities, $24 \mathrm{~h}$ after fertilization. In all treatments, temperature and salinity were $24^{\circ} \mathrm{C}$ and $30 \mathrm{ppt}$ respectively.

\begin{tabular}{|c|c|c|c|c|c|c|c|}
\hline \multirow{2}{*}{ Experiments } & & \multicolumn{5}{|c|}{ Egg density per litre } & \multirow[b]{2}{*}{$1 \times 10^{6}$} \\
\hline & & $1 \times 10^{4}$ & $2.5 \times 10^{4}$ & $5 \times 10^{4}$ & $1 \times 10^{5}$ & $5 \times 10^{5}$ & \\
\hline \multirow[t]{2}{*}{1} & A & 70.0 & 71.7 & 58.3 & 50.8 & 8.2 & 6.3 \\
\hline & B & 74.4 & 73.8 & 59.7 & 52.7 & 7.8 & 4.9 \\
\hline \multirow[t]{2}{*}{2} & A & 80.3 & 73.1 & 72.7 & 55.4 & 16.8 & 5.4 \\
\hline & $\mathrm{B}$ & 83.7 & 82.1 & 76.0 & 59.8 & 8.7 & 6.9 \\
\hline \multirow[t]{2}{*}{3} & A & 91.6 & 87.0 & 77.8 & 74.5 & 11.5 & 8.4 \\
\hline & B & 90.3 & 89.6 & 84.1 & 72.1 & 9.7 & 7.3 \\
\hline $\bar{x}$ & & 81.7 & |79.6 & 71.4 & 60.9 & 10.5 & 6.5 \\
\hline S.D. & & 8.58 & 7.74 & 10.33 & 10.11 & 3.38 & 1.28 \\
\hline
\end{tabular}


and $25^{\circ} \mathrm{C}$ and at 27 and 37 ppt. Optimal temperature-salinity conditions for normal embryonic development of S. cucullata from Indian waters have been estimated to occur at temperatures of $25^{\circ}-30^{\circ} \mathrm{C}$ with salinities 25-35 ppt (Kalyanasundaram \& Ramamoorthi, 1986). Fertilization in C. iredalei allowing development to normal D-larvae occurred over a wide range of salinity and temperature, between 10 to $40 \mathrm{ppt}$ and 14 to $34^{\circ} \mathrm{C}$. Optimal salinity and temperature for em bryonic development of this species was 25-35 ppt and at temperatures $19-29^{\circ} \mathrm{C}$. Thus optimal salinity and temperature for embryonic development in $C$. iredalei was wide. The habitat of $C$. iredalei is in estuarine areas, the salinity is a relatively unstable factor (5 to $34 \mathrm{ppt}$ ). Everyday, tidal flow changes the salinity and temperature conditions.

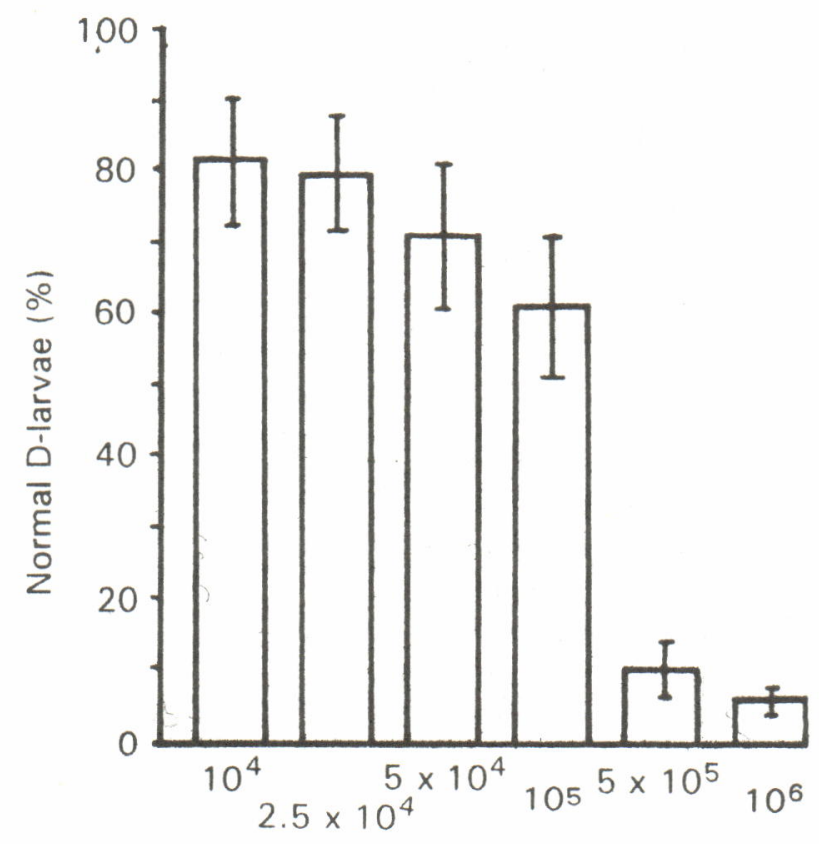

Egg density per litre

Figure 5. C. iredalei. Percentage of eggs that developed into normal D-larvae at different egg densities, $24 \mathrm{~h}$ after fertilization. Salintiy and temperture were $30 \mathrm{o} / \mathrm{oo}$ and $24^{\circ} \mathrm{C}$. Standard deviations are also shown.

Davis (1958), Loosanoff \& Davis (1963) and Lough \& Gonor (1971) stated that temperature and salinity conditions, at which the parent stock develop gonads and spawn, influences the tolerances of the embryos. If this is so for the present species the conditioning of adult oysters in the laboratory could affect the tolerance limit of salinity and temperature for embryonic development.

It is therefore apparent that the optimal temperature for embryonic development for practical purposes in the tropics is best around ambient temperature, $24^{\circ}$ to $29^{\circ} \mathrm{C}$, and at salinity about 28 to 32 ppt. Ver (1986) and Kalyana- sudaram \& Ramamoorthi (1986) report similar findings.

Observations on D-larvae $30 \mathrm{~h}$ after fertilization (i.e. before onset of feeding) showed that there were significant differences of mean length of larvae between different salinities and temperature (20 to $35 \mathrm{ppt}$ ) and $19^{\circ}$ to $29^{\circ} \mathrm{C}$ ). The highest mean length was recorded at a salinity of only 25 ppt and at temperature of $29^{\circ} \mathrm{C}$. Davis (1958) reported that for C. virginica larvae a salinity of 17.5 ppt. was optimum for growth even though the adults occur in higher salinities. The temperature $\left(29^{\circ} \mathrm{C}\right)$ for maximum growth of the present species was within the range of ambient temperature. 


\section{Effect of Egg Density}

With C. gigas, Walne (1981) reported that poor fertilizations can be correlated with increase in age of gametes. He added that egg and sperm mixing made within $1 \mathrm{~h}$ of release will give a good yield of normal D-larvae but delays of $3 \mathrm{~h}$ and $5 \mathrm{~h}$ reduce the yield to $50 \%$ and $25 \%$. From the same species, Helm \& Millican (1977) found that delayed fertilization of more than 60-90 minutes after gamete release, greatly reduced the percentage of normal larvae. The egg densities of 10-100 per ml with ratios of 100 to 1000 sperm per egg obtained equally good results for $C$. gigas (Walne, 1981). Dos Santos \& Nascimento (1985) reported the best densities of $C$. rhizophorae eggs for the production of normal D-larvae were $1 \times 10^{4}-4 \times 10^{4}$ per litre. In this work with $C$. iredalei, numbers of sperm were 100 per egg and crosses made within $1 \mathrm{~h}$ after release. The best egg densities were $1 \times 10^{4}-5 \times 10^{4}$ per litre. In this experiment, egg density started at $1 \times 10^{4}$ per litre with assumption that more D-larvae and higher percentages of D-larvae are produced by eggs incubated at low density levels. The low percentage of normal D-larvae as a result of overcrowding of eggs may be caused by lack of sufficient oxygen and presence of waste products as suggested by Blaxter (1962) and Gruffydd \& Beaumont (1970).

\section{ACKNOWLEDGMENTS}

The author wish to record his appreciation of citicism and guidance of Dr. John Moyse from the school of Biological Sciences, University College of Swansea, UK. during the experiments and preparation of the manuscript.

\section{REFERENCES}

Amemiya, I. 1928. Notes on experiments on the early developmental stages of the Portuguese, American and English native oysters, with special reference to the effect of varying salinity. J. mar. biol. Ass. U.K., 14, 161-175.

Blaxter, J.H.S. 1962. Herring rearing-IV- Rearing beyond the yolk sae stage. Mar. Res., (1), 1-18.

Calabrese, A. 1969. Individual and combined effects of salinity and temperature on embryos and larvae of the coot clam, Mulinia lateralis (Say). Biol. Bull., 137, 417-428.
Calabrese, A. and H.C. Davis. 1966. The $\mathrm{pH}$ tolerance of embryos and larvae of Mercenaria mercenaria and C. virginica Biol. Bull., 131, 427-436.

Calabrese, A. and H.C. Davis. 1970. Tolerances and requirements of embryos and larvae of bivalve molluscs. Hegol. Wiss. Meeresunters., 20, 553-564.

Davis, H.C. 1958. Survival and growth of clam and oyster larvae at different salinities. Biol. Bull., 114, 296-307.

Davis, H.C. and A. Calabrese. 1964. Combined effects of temperature and salinity on development of eggs and growth of larvae of $M$. mercenaria and $C$. virginica. Fish. Bull., 63, 643-655.

Dos Santos, A.E. and I.A. Nascimento. 1985. Influence of gamete density, salinity and temperature on the normal embryonic development of the mangrove oyster Crassostrea rhizophorae Guilding, 1828. Aquaculture, 47, 335-352.

Galtsoff, P.S. 1964. The American oyster: Crassostrea virginica. Fish. Bull., 64, 1-480.

Gruffydd, L.D. and A.R. Beaumont. 1970. Determination of the concentration of eggs and spermatozoa for the production of normal larvae in Pecten maximus (Mollusca, Lamellibranchia). Helgol. Wiss. Meeresunters., 20, 486-497.

Helm, M.M. and P.F. Millican. 1977. Experiments in the hatchery rearing of Pacific oyster larvae $(C$. gigas Thunberg). Aquaculture, 11, 1-12.

Hrs-brenko, M. and A. Calabrese. 1969. The combined effects of salinity and temperature on embryos and larvae of the mussel Mytilus edulis. Mar. Biol., 4, 224-226.

Kalyanasundaram, M. and K. Rama-moorthi. 1986. Temperature and salinity requirements for embryonic development of Saccostrea cucullata (Born). Mahasagar-Bull. Natl. Inst. Oceanography, 19 (1), 53-55.

Loosanoff, V.L. and H.c. Davis. 1963. Rearing of bivalve molluscs. Adv. Mar. Biol., 1, 1-136.

Lough, R.G. and J.J. Gonor. 1971. Early embryonic stages of Adula californiensis (Pelecypoda: Mytilidae) and the effect of temperature and salinity on development rate. Mar. Biol., 8, 118-125.

Sokal, R.R. and F.J. Rohlf. 1981. Biometry. $2^{\text {nd }}$ ed., W.H. Freeman Co., San Fransisco, 859 p.

Tettelbach, S.T. and E.W. Rhodes. 1981. Combined effects of temperature and salinity on embryos and larvae of the Northern Bay scallop Argopecten irradians irradians. Mar. Biol., 63, 249-256. 
Ver, L.M.M. 1986. Early development of Crassostrea iredalei (Faustino, 1932) (Bivalvia: Ostreidae), with notes on the structure of the larval hinge. Veliger, 29 (1), 78-85.

Walne, P.R. 1974. Culture of bivalve molluscs. 50
Years' experience at Conwy. Fishing News Books, Farnham, 189 p.

Walne, P.R. 1981. Culture of shellfish. In: Aquarium Systems, ed. A.D. Hawkins, Academic Press, 347. 371. 